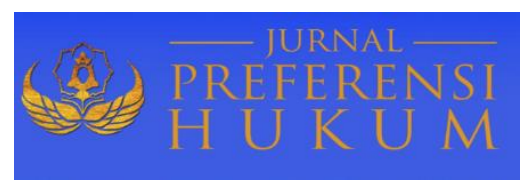

Jurnal Preferensi Hukum | ISSN: XXXX | E-ISSN: XXXX

Vol. 1 No. 1 - Juli 2020 hal. 59-67| Available online at https://www.ejournal.warmadewa.ac.id/index.php/juprehum

\title{
KEDUDUKAN KRAMA DESA YANG BERALIH AGAMA DALAM TANAH KARANG DESA DI DESA ADAT CANGGU BADUNG
}

\author{
I Komang Suartama Yasa \\ Fakultas Hukum Universitas Warmadewa, Denpasar - Bali, Indonesia
}

\begin{abstract}
Abstrak
Status dan fungsi tanah-tanah adat menyebabkan masalah pertanahan menjadi kompleks, yang dapat menjadi sumber permasalahan hukum dan sosial yang tampak dalam berbagai bentuk sengketa atas tanah. Demikian pula halnya terhadap tanah pekarangan desa tidak luput dari sengketa. Ada banyak faktor yang menyebabkan sampai terjadinya sengketa tanah pekarangan desa. Tujuan dari penelitian ini adalah untuk mengetahui hak dan kewajiban krama desa yang menempati tanah karang desa dan untuk mengetahui kedudukan krama desa yang tidak lagi beragama Hindu terhadap tanah karang desa sesuai dengan awig-awig Desa Adat Canggu Badung. Jenis penelitian yang dipergunakan adalah penelitian hukum empiris. Hasil penelitian ini adalah 1) Hak dan kewajiban krama desa yang menempati tanah karang desa sesuai dengan awig-awig Desa Adat Canggu Badung adalah untuk menempati tanah karang desa, mengingat krama desa yang menempati tanah karang desa telah diatur dalam Awig-Awig Desa Adat Canggu, Pawos 4 Ayat (1) serta berkewajiban ikut mebanjar, melaksanakan ayahan desa dan membayar iuran. 2) Kedudukan krama desa yang tidak lagi beragama Hindu terhadap tanah karang desa sesuai dengan awig-awig Desa Adat Canggu Badung setiap krama desa yang beralih agama, maka krama tersebut disebut krama tamiu. Berdasarkan hal tersebut, maka semua harta atau fasilitas desa adat wajib diserahkan kembali kepada desa adat, termasuk tanah karang desa yang ditempatinya, seperti tercantum dalam Pararem Desa Adat Canggu, Pawos 4 Ayat (3).
\end{abstract}

Kata Kunci: Beralih Agama; Desa Adat; Krama Desa; Tanah Karang Desa

\begin{abstract}
The status and function of customary land causes land problems to become complex, which can be a source of legal and social problems that appear in various forms of land disputes. Likewise with respect to the village plots, it is not free from disputes. There are many factors that lead to the disputes in village yards. The objectives of this study is to examine the rights and obligations of the village manners who occupy the village reefland and to examine the position of the village manners who are no longer Hindu towards the village coral land are in accordance with the Canggu Badung Adig village awig-awig. The type of study used is empirical legal research. The results of this study is 1) the rights and obligations of the village manners who occupy the village reef land in accordance with awig-awig Adat Canggu Badung Village is to occupy the village coral land, bearing in mind the village manners who occupy the village coral land have been regulated in Awig-Awig Canggu Adat Village, Pawos 4 Paragraph (1) and is obliged to participate in retribution, carrying out village directives and paying contributions. 2) The position of the village manners who are no longer Hindu towards the village coral land is in accordance with the awig-awig of the Traditional Village of Canggu Badung every village manners who convert, then the manners are called tamiu manners. Based on this, all the assets or facilities of the customary village must be returned to the customary village, including the village coral land it occupies, as stated in the Pararem of the Canggu Customary Village, Pawos 4 Paragraph (3).
\end{abstract}

Keywords: Converting Religion; Traditional Village; Krama Village; Land of Village 


\section{PENDAHULUAN}

Berkembangnya kemajuan teknologi transportasi dan arus informasi, menyebabkan tantangan yang dihadapi masyarakat Bali semakin beragam masalah yang dihadapi termasuk dalam hubungannya dengan keyakinan beragama. Pengaruh timbal balik antara agama dan budaya, dalam arti agama mempengaruhi kebudayaan, kelompok masyarakat, suku bangsa (Bauto, 2016). Masalah yang muncul antara lain sikap hidup individualisme dan konsumerisme. Faktor penyebab dan dampak yang ditimbulkan akibat dari perilaku konsumtif masyarakat, (Urbanus \& Febianti, 2017). Masalah-masalah yang muncul ini sebagai akibat kearipan lokal patut diatasi secara tepat melalui pemahaman dan pendalaman. "Pendalaman makna dari kearifan lokal kepada seluruh masyarakat Bali sehingga budaya Bali tetap ajeg" (Ardana, 2007:6). Selain itu kesadaran budaya masyarakat perlu ditingkatkan sehingga muncul kecintaan pada budaya sendiri. Sebagai penopang yang tangguh dari budaya Bali adalah lembaga tradisional seperti: "desa, banjar perlu dilestarikan keberadaannya" (Ardana, 2007:15).

Desa adat sebagai kesatuan masyarakat hukum adat berdasarkan filosofi Tri Hitta Karana yang berasal dari kearifan lokal Sad Kerthi. Tri Hitta Karana yang merupakan salah satu ajaran dalam agama Hindu yang pada mengajarkan tentang keseimbangan antara manusia dengan Tuhan, manusia dengan manusia, dan manusia dengan lingkungannya (Sumunar, Suparmini, \& Setyawati, 2017).Dengan dijiwai ajaran agama Hindu dan nilai-nilai budaya serta kearifan lokal yang hidup di Bali, sangat besar peranannya dalam pembangunan masyarakat, bangsa, dan negara sehingga perlu diayomi, dilindungi, dibina, dikembangkan, dan diberdayakan guna mewujudkan kehidupan krama Bali yang berdaulat secara politik, berdikari secara ekonomi, dan berkepribadian dalam kebudayaan.

Dalam Pasal 1 angka 8 Peraturan Daerah Propinsi Bali Nomor 4 Tahun 2019 tentang Desa Adat di Bali ditegaskan:

Desa Adat adalah kesatuan masyarakat hukum adat di Bali yang memiliki wilayah, kedudukan, susunan asli, hak-hak tradisional, harta kekayaan sendiri, tradisi, tata krama pergaulan hidup masyarakat secara turun-temurun dalam ikatan tempat suci (Kahyangan Tiga atau Kahyangan Desa), tugas dan kewenangannya serta hak mengatur dan mengurus rumah tangganya sendiri.

Peraturan Daerah Provinsi Bali Nomor 4 Tahun 2019 tentang Desa Adat, yang disahkan pada tanggal 02 April 2019 dan diundangkan tanggal 28 Mei 2019 menggantikan Peraturan Daerah Provinsi Bali Nomor 3 Tahun 2001. Perda ini pada prinsipnya tetap berpegang pada falsafah Tri Hita Karana, yang meliputi unsur parhyangan, pawongan, dan palemahan. Namun, ada pula hal-hal baru yang dimaksudkan untuk menyesuaikan diri dengan perkembangan masyarakat di era otonomi daerah.

Hak tersebut sesuai dengan pendapat I Made Suwitra yang menegaskan bahwa Tanah-tanah adat seperti PKD yang dikuasai secara individu di dalamnya terkandung konsep Tri Hitta Karana, yaitu berupa Pahrayangan yang berwujud Merajan (believe system), Palemahan yang berwujud wilayah perumahan (artifact system), dan Pawongan yang berwujud anggota keluarga yang tinggal disitu (social system), yang notabena sebagai krama banjar dan krama desa adat, semuanya ini sudah barang tentu diatur dalam Awig-awig. Tanah-tanah adat ini masih diyakini mempunyai sifat yang religio magis, sehingga kehidupan krama desa diperuntukan untuk mengabdikan kepada Tuhan yang berstana di setiap pura Kahyangan Tiga dan pura lain yang diempon oleh krama desa yang ada di wilayah desa adat. Kondisi ini tidak terlepas dari perspektif historis yang melatarbelakangi munculnya desa adat menurut isi cerita dalam lontar Markandia Purana (Suwitra, 2011:73).

Perkembangan dan perubahan yang terjadi dalam masyarakat Bali karena pengaruh modernisasi dan globalisasi di sektor pariwisata telah menyebabkan tanah-tanah adat Bali mengalami perubahan status dan fungsinya. Hal ini tampak jelas didaerah-daerah yang industri pariwisatanya berkembang pesat, seperti di Kabupaten Badung. Pengembangan industri pariwisata seperti membangun penginapan, toko kesenian dan fasilitas penunjang lainnya, adakalanya memakai tanah-tanah adat. Hal inilah yang dapat menimbulkan perubahan status dan fungsi tanah-tanah adat, yang dapat berpengaruh terhadap hak-hak atas tanah

Permasalahan tanah yang kompleks diakibatkan oleh status dan fungsi tanah-tanah adat (Suryawan, 2018) dapat menjadi sumber permasalahan hukum dan sosial yang tampak dalam berbagai bentuk sengketa atas tanah. Demikian pula halnya terhadap tanah pekarangan desa tidak luput dari sengketa. Ada banyak faktor yang menyebabkan sampai terjadinya sengketa tanah pekarangan desa. 
Fenomena tanah karang desa banyak terjadi seperti antara lain, dimana awalnya tanah karang desa tersebut ditempatkan oleh ayah dan ibu, keluarga ini memiliki satu orang anak perempuan, kawin dengan laki-laki non Hindu dan tinggal bersama di tanah karang desa tersebut, lama kelamaan ayahnya meninggal, tidak berselang lama disusul oleh ibunya. Akhirnya tinggal anak perempuan tersebut yang telah kawin dan telah beralih agama bersama suaminya yang non Hindu.

Begitu pula yang terjadi di Desa Adat Canggu Badung keluarga kakak beradik yang tinggal di satu tanah karang desa, yang hidup harmonis, rukun dan damai. Kakaknya mempunyai dua orang anak, lakilaki dan perempuan. Yang perempuan sudah kawin keluar. Sedangkan adiknya mempunyai anak, yaitu anak perempuan kawin dengan laki-laki non Hindu, karena kawin dengan laki-laki non Hindu si perempuan tersebut beralih agama (ikut suami), setelah kawin tetap tinggal di rumah orang tuanya, makhlum orang tuanya sudah tua dan sakit- sakitan, sehingga suami istri itu memutuskan untuk tinggal bersama. Singkat cerita, kedua orang tuanya ibu dan bapaknya meninggal, biasa diaben seperti kebanyakan orang di Desa Adat Canggu tersebut. Lama-kelamaan anaknya ini tetap tinggal di rumah orang tuanya, yang akhirnya suami istri ini memiliki anak dan tetap tinggal di tanah karang desa tersebut. Inilah yang sering diperguncingkan oleh keluarga.

Terkait dengan kasus adat yang dipaparkan tersebut di atas, kejadian/kasus adat yang terjadi di Desa Adat Canggu Badung ini adalah kasus murni adat yang belum diatur dalam peraturan perundangan negara, yakni krama desa yang beralih agama, hak dan kewajiban menempati tanah karang desa dicabut diganti dengan warga lain yang terdekat sesuai dengan keputusan paruman Desa Adat Canggu Badung pada tanggal 27 Nopember 2008, yang bertempat di Balai Banjar., sehingga untuk itu perlu diadakan penelitian.

Adapun beberapa penelitian terkait dengan penelitian sekarang ini telah dikaji sebelumnya, di antaranya Aspriani, Budiono, \& Sirtha (2013) berjudul "Status Kepemilikan Tanah Druwe Desa di Bali". Hasil penelitiannya menunjukkan bahwa berdasarkan perturan Perundangan- undangan yang berlaku khususnya kususnya Pasal II Ketentuan-ketentuan Konversi, Undang-Undang Nomor 5 Tahun 1960, tanah druwe desa mendapatkan pengakuan dalam hukum pertanahan nasional. Namun menurut Peraturan Pemerintah Nomor 38 Tahun 1963 Desa Pakraman tidak termnasuk badan hukum yang dapat mempunyai hak milik atas tanah. Selanjutnya, (Dewi, 2016); Wiguna (2018) juga mengkaji penelitian serupa. Wiguna (2018) mengkaji tentang "Memahami Pertalian Desa Pakraman di Bali Dengan Karang Ayahan Sebagai Bagian Dari Palemahan Berdasarkan Konsep Tri Hita Karana". Hasil penelitiannya menunjukkan bahwa eksistensi karang ayahan sangat bergantung dengan eksistensi suatu desa pakraman. Dalam rangka menjaga keberlangsungan eksistensi dari masyarakat hukum adat termasuk juga desa pakraman, maka memberikan pengakuan, perlindungan dan kepastian hukum terhadap keberadaan masyarakat hukum adat merupakan langkah strategis yang harus dilakukan oleh Negara dalam merawat kebhinekaan Bangsa Indonesia. Tentu saja pengakuan dan perlindungan tersebut harus didasarkan pada norma-norma hukum dalam peraturan perundang-undangan. Berdasarkan norma-norma hukum itu nantinya diharapkan dapat memberikan kepastian hukum terhadap eksistensi masyarakat hukum adat beserta hak-hak tradisionalnya yang melekat termasuk hak atas tanah-tanah adat (karang ayahan). Penelitian serupa lainnya telah dikaji sebelumnya oleh Trinaya D (2019) dan Wirawan, Sukadana, \& Suryanata (2019) yang mengkaji tentang "Status Tanah Karang Desa Di Desa Pakraman Selat Belega". Hasil penelitiannya menunjukkan bahwa kewajiban manusia desa sebagai pemegang tanah karang desa antara berada di Desa Pakraman Selat sesuai dengan Awig-Awig dan Pararem Desa, menjadi milik para pengarep, tedun mebanjar, ngayah di desa pakraman dan/atau Kahyangan Tiga dan mengeluarkan Pepeson, patuh dan patuh pada awig-awig di desa Pakraman dan telah menjadi kebiasaan adat Banjar.

Berdasarkan latar belakang tersebut diatas, penelitian ini bertujuan untuk mengetahui hak dan kewajiban krama desa yang menempati tanah karang desa dan untuk mengetahui kedudukan krama desa yang tidak lagi beragama Hindu terhadap tanah karang desa sesuai dengan awig-awig Desa Adat Canggu Badung.

\section{METODE PENELITIAN}

Penelitian ini menggunakan penelitian hukum empiris yaitu penelitian berupa studi-studi empiris untuk menemukan teori-teori mengenai proses terjadinya dan mengenai proses bekerjanya hukum di dalam 
masyarakat. Menurut Waluyo (2002), penelitian hukum empiris merupakan jenis penelitian hukum sosiologis dan dapat pula disebut dengan penelitian lapangan, yaitu mengkaji ketentuan hukum yang berlaku serta apa yang terjadi dalam kenyataannya di masyarkat. Penelitian ini menggunakan pendekatan sosiologis. Teknik Pengumpulan data yang digunakan dalam penelitian ini adalah Teknik wawancara dan Teknik Observasi/Pengamatan.

\section{HASIL DAN PEMBAHASAN}

\section{Hak Dan Kewajiban Krama Desa Yang Menempati Karang Desa}

Sebelum Indonesia memproklamasikan kemerdekaannya, di dalam masyarakat adat telah terdapat penguasaan dan pemilikan tanah yang diatur sesuai dengan ketentuan hukum adat yang berlaku dalam masyarakat tersebut. Ketentuan yang mengatur mengenai penguasaan atas tanah yang terdapat dalam masyarakat bercirikan "tidak tertulis" (Supriadi, 2012:41).

Ada dua hal yang menyebabkan hukum tanah memiliki fungsi yang penting dalam kehidupan masyarakat hukum adat yaitu:

(1) Karena sifatnya, yaitu merupakan satu-satunya benda yang kekayaan meskipun mengalami keadaan yang bagaimana pun akan masih bersifat tetap dalam keadaan seperti semula dan bahkan menjadi lebih menguntungkan.

(2) Karena faktanya, yaitu suatu kenyataan bahwa tanah itu merupakan tempat tinggal persekutuan, memberi penghidupan bagi persekutuan, merupakantempat dimana para warga persekutuan yang meninggal dunia dikebumikan (Dharmayuda, 1987:15).

Salah satu cerminan politik hukum di bidang pertanahan dalam Undang- Undang Republik Indonesia Nomor 5 Tahun 1960 tentang Peraturan Dasar Pokok-Pokok Agraria (UUPA), adalah adanya unifikasi hukum dalam bidang hukum agraria atau pertanahan di Indonesia, walaupun unifikasi tersebut bersifat unik, karena masih memberikan kemungkinan berlakunya hukum adat dan agama. Tetapi, adanya UUPA merupakan tonggak yang sangat penting dalam sejarah perkembangan agraria/pertanahan di Indonesia.

Makna pernyataan istilah berdasarkan atas dan ialah hukum adat tersebut, menunjukkan adanya hubungan fungsional antara Hukum Adat dan UUPA. Tanah-tanah adat di Bali dapat dibedakan menjadi beberapa jenis yaitu:

(1) Tanah desa, yaitu tanah yang dikuasai oleh desa adat yang didapat baik melalui pembelian atau usaha lainnya yang termasuk druwe tanah desa adat antar lain tanah pasar, tanah lapang, tanah kuburan, tanah bukti dll.

(2) Tanah laba pura, yaitu tanah yang dimiliki dan dikuasai oleh desa adat yang khusus diperuntukan untuk keperluan pura.

(3) Tanah pekarangan desa (PKD) yaitu tanah yang dikuasai oleh desa yang diberikan kepada krama desa untuk tempat tinggal mereka.

(4) Tanah ayahan desa, yaitu tanah yang dikuasai oleh desa yang penggarapannya diserahkan kepada krama yang melekatkannya pada suatu kewajiban berupa ayahan.

(5) Tanah yang dikuasai oleh desa adat yaitu tanah druwe desa dan laba pura

(6) Tanah adat yang dikuasai oleh perseorangan (Surpha, 2012: 22).

Lebih lanjut I Made Suwitra menjelaskan bahwa "di Bali dikenal dengan tanah adat dalam berbagai jenisnya seperti tanah laba pura, laba banjar, laba desa (adat), tanah pekarangan desa (PKD), tanah ayahan desa (AyDs), tanah setra, tanah pasar, tanah lapang, tanah pauman di Kabupaten Karangasem" (Suwitra, 2011:7).

Hubungan fungsional ini juga merefleksikan adanya cita (tujuan) hukum yang tidak hanya secara konvensional ditujukan untuk menjaga keteraturan dan ketertiban sosial (social order) dalam masyarakat yang fungsinya hanya menekankan sebagai instrumen pengawasan sosial (social control). Dalam masyarakat yang lebih kompleks cita hukum kemudian dikembangkan sebagai alat untuk merekayasa kehidupan sosial (social engineering) untuk mewujudkan nilai kepastian hukum. Namun, cita hukum hendaknya dapat ditingkatkan agar dapat memainkan peran sebagai instrumen untuk memelihara dan memperkokoh integrasi bangsa dalam masyarakat yang bercorak multikultural. Secara filosofis pembentukan UUPA ditujukan untuk mewujudkan apa yang digariskan dalam Pasal 33 ayat (3) UndangUndang Dasar Negara Republik Indonesia Tahun 1945 (yang selanjutnya disebut UUD Negara RI Tahun 
1945), bahwa Bumi, air dan kekayaan alam yang terkandung di dalamnya dikuasai oleh negara dan dipergunakan untuk sebesar-besarnya kemakmuran rakyat.

Konsep Laba, kurang lebih berarti pecaru, segehan, sesuatu yang disuguhkan atau dipersembahkan kepada Hyang Widhi, sebuah konsep yang bermakna kesucian. Jika dikaitkan dengan tanah dan Pura, berarti tanah yang di- segeh-kan, dipersembahkan untuk kepentingan pura, kepentingan ritual, yang disebut dengan tanah laba Pura.

Tanah ini sengaja disediakan oleh raja, sebagai perwujudan pelaksanaan unsur parahyangan dalam konsep Tri Hita Karana, dalam kehidupan masyarakat desa. Masyarakat tidak akan bisa berkembang dinamis, jika raja hanya memberikan perhatian pada unsur Tri Hita Karana lainnya pawongan (interaksi manusia) dan palemahan (lingkungan alam, binatang dan tumbuh-tumbuhan), tetapi juga parahyangan (pemujaan Tuhan). Ketiga unsur ini harus berjalan dengan baik dan saling mengisi.

Untuk memudahkan implementasinya, dibuatlah lembaga-lembaga pelaksana. Dalam mengatur kehidupan manusia dibuat banjar, di atas banjar ada kaperbekelan (desa). Sedangkan untuk mengatur pengolahan sumber daya alam dibuat berbagai organisasi (sekeha) seperti sekeha subak, manyi (panen), semal (tupai), dan sebagainya.

Sementara untuk parahyangan dibuat sekeha pemaksan. Ketiga lembaga ini berada di bawah koordinasi pemekel (perbekel, lurah) dan bendesa adat, dan mereka bertanggungjawab kepada para manca. Sebagaimana halnya dalam sekeha subak, krama (anggota) sekeha pemaksan juga melintasi banjar, artinya berasal dari berbagai banjar dan sebisa-bisanya dalam satu lingkungan desa adat.

Sesuai wawancara penulis dengan I Nyoman Sujapa Bendesa Adat Canggu Bandung yang mengatakan bahwa: Segala sesuatu yang berkaitan dengan Pura kahyangan tiga dan Pura lainnya yang ada dalam desa tersebut, terutama dalam perawatan dan piodalan menjadi tanggungjawab dari kelihan pemaksan. Dalam menjalankan tugasnya kelihan dibantu oleh penyarikan (juru tulis) dan beberapa kasinoman (seksi komunikasi). Sementara untuk kepentingan ritual, diserahkan kepada pemangku. Semua biaya untuk keperluan tersebut diperoleh dari hasil pengolahan tanah laba Pura, yang sering juga disebut tanah druwe Pura. (Wawancara pada tanggal 21 Pebruari 2020).

Lebih lanjut dikatakan oleh I Gede Dedik Suantika, Kelian Banjar Adat Babakan mengatakan bahwa: Tanah druwe ini bisa berupa pekarangan, tegalan atau sawah. Tanah pekarangan biasanya dihuni oleh keluarga atau pengurus pemaksan secara turun-temurun. Atas kemudahan yang diperolehnya itu, mereka wajib ngaturan ayahan ke pura, mempersebahkan tenaga dan materi, seperti melakukan gotong royong membersihkan dan memperbaiki pura, termasuk juga dalam pelaksanaan upacara adat. Materinya, berupa persembahan peturunan (iuran) dan pepeson (beras, janur, buah-buahan, hewan, dan sebagainya). Sedangkan untuk tanah tegalan dan sawah dikerjakan dengan sistem bagi hasil. Makin luas tanah laba Pura dalam suatu desa adat (tergantung dari jumlah Pura), semakin banyak pula petani penggarapnya (Wawancara pada tanggal 22 Pebruari 2020).

Implementasi konsep Tri Hita Karana itu, mirip dengan sosialisme kuno, namun masyarakat Bali belum layak disebut masyarakat sosialis, karena masih diakuinya hak-hak individu atas tanah. Namun tidak juga dapat disebut masyarakat demokratis murni, karena masih sarat dengan prinsip feodalisme.

Kiranya lebih tepat disebut masyarakat tradisional patrimonial, yang sangat taat pada perintah dari atas. Kehidupan masyarakat yang berdasarkan konsep rong telu, kini sedang mengalami perubahan bukan menjadi lebih demokratis tetapi menuju kepunahan. Sementara itu, sebagian besar pejabat berkoar, bahwa pembangunan Bali sudah berdasarkan konsep Tri Hita Karana. Akan tetapi dalam kenyataannya satu persatu unsur Tri Hita Karana dibabat atas nama kepentingan pembangunan dan ekonomi pariwisata.

Setelah membabat sebagian besar subak, terutama yang di kota, dengan berbagai dalih, kini perhatian dialihkan ke tanah karang desa dan laba Pura. Perluasan eksploitasi ke ranah sosial-religius ini diawali dengan keluarnya perangkat hukum berupa Peraturan Menteri Dalam Negeri Nomor 16 Tahun 1975 yang mengatur pendaftaran tanah dan pemberian sertifikat.

Dalam peraturan ini, tanah druwe dapat disertifikatkan setelah mendapat persetujuan dari paruman (rapat) desa adat. Jalannya rapat ini sering kali mudah diatur sesuai kehendak penguasa, karena desa adat tidak terlepas dari intervensi desa dinas dan aparat keamanan di tingkat desa yang sering memanfaatkan masyarakat desa untuk memperjuangkan keinginannya. 
Menurut I Nyoman Sujapa, Bendesa Desa Adat Canggu Badung mengatakan: Tanah pekarangan desa merupakan hak milik desa adat, yang penguasaannya diserahkan kepada krama desanya, maka hak yang diperoleh krama desa adalah hak pakai dan pemegang tanah pekarangan desa dibebani oleh sejumlah hak dan kewajiban. Hak dari krama desa yang menempati tanah karang desa adalah memelihara tanah tersebut, dengan memagari, membuat penyengker (tembok), menanam tumbuh-tumbuhan, sedangkan kewajiban antara lain: membayar iuran, taat kepada awig-awig, menjadi warga/krama desa, dan tinggal di tanah tersebut (Wawancara pada tanggal 21 Pebruari 2020).

\section{Kedudukan Krama Desa yang Telah Beralih dari Agama Hindu ke Agama Lain dalam Tanah Karang Desa}

Hak krama desa untuk melakukan sesuatu terhadap tanah pekarangan desa adalah hak untuk menempati, memanfaatkan dan mengusahakan tanah karang tersebut sesuai dengan keinginan mereka karena syaratsyarat untuk menempati tanah tersebut telah mereka penuhi, tetapi tidaklah berarti kekuasaan atau hak yang diberikan itu tidak terbatas. Mereka berhak untuk membangun rumah diatasnya, menanam pohon-pohon yang diinginkan atau memelihara binatang, membangun tempat persembahyangan untuk para leluhur mereka atau bangunan-bangunan lainya asalkan mereka tidak melampaui batas- batas yang telah ditetapkan dalam awig-awig atau paruman desa.

Lebih lanjut dijelaskan krama desa yang menempati tanah karang desa adalah "melekat kewajiban krama desa kepada desa yang disebut ayahan, baik berupa tenaga maupun materi". Begitu juga I Gusti Ngurah Gorda menjelaskan bahwa:

Atas kemudahan yang diperolehnya itu, mereka wajib ngaturan ayahan ke pura, mempersebahkan tenaga dan materi, seperti melakukan gotong royong membersihkan dan memperbaiki pura, termasuk juga dalam pelaksanaan upacara adat. Materinya, berupa persembahan peturunan (iuran) dan pepeson (beras, janur, buah-buahan, hewan, dan sebagainya). Sedangkan untuk tanah tegalan dan sawah dikerjakan dengan sistem bagi hasil. Makin luas tanah laba Pura dalam suatu desa adat (tergantung dari jumlah Pura), semakin banyak pula petani penggarapnya. (Gorda, 1999:38).

Terhadap hal tersebut, I Nyoman Sujapa, Bendesa Desa Adat Canggu Badung menegaskan bahwa : Krama desa yang telah beralih agama, tidak lagi melaksanakan hak dan kewajibannya selaku krama seperti kewajiban membayar peturunan, ngayahang banjar (sangkep) petedunan gotong royong, dengan demikian haknya juga otomatis hilang yaitu menempati tanah karang desa.(Wawancara pada tanggal 21 Pebruari 2020).

Lebih lanjut I Nyoman Sujapa, Bendesa Desa Adat Canggu Badung menjelaskan bahwa: Dalam hal Krama Desa Adat Canggu Badung yang tidak lagi beragama Hindu dan menempati tanah karang desa, hak dan kewajibannya sudah hilang alias tidak lagi memiliki hak untuk menempati tanah karang desa, mengingat krama desa yang menempati tanah karang desa telah diatur dalam Awig-Awig Desa Adat Canggu Badung yaitu yang beragama Hindu (Wawancara pada tanggal 21 Pebruari 2020).

Krama Desa Adat Canggu Badung, dalam hal menempati tanah karang desa, memiliki kedudukan yang berbeda beda sesuai dengan keadaan dari krama desa tersebut. Hal tersebut dapat dilihat dari penegasan pada Pararem Pengele Desa Adat Canggu Badung Pawos 4. Pawos 4 Swadharmaning krama desa lan tamiu:

1. Swadharmaning Krama Adat, luwire:

ha. Satinut ring sadaging Awig-awig, Pararem lan Pasuara Desa Adat. na. Tan maren sareng mautsaha, mangda Desane prasida nyujur patitis Desa Adat Canggu.

ca. Sayaga sareng natakin panes tis kertiyasan Desa Adat. ra. Keni peturunan, peson-peson lan ayahan mamungkul.

2. Swadharmaning Krama Tamiu inggih punika:

ha. Satinut ring tetiwak Desa Adat ngeninin indik ngupadi kasukertan Desa Adat ring sekala, niskala.

na. Tan kengin nungkasin keriyasan Desa Adat.

ca. Patut mesadok ring kelihan banjar ritatkala nerima tamiu nyantos lintang ring 24 jam. 
ra. Ngaturang punia lan ayah ring parhyangan manut kabuatang.

3. Swadharmaning Tamiu, inggih punika:

ha. Satinut ring tetiwak Desa Adat ngeninin indik pawongan lan palemahan.

na. Tan kengin nungkasin kertiyasan Desa Adat Canggu.

ca. Patut mesadok ring kelihan banjar ritatkala nerima tamu nyantos lintang ring 24 jam.

ra. Keni punia manut kabuatang.

Terjemahan Pawos 4

Kewajiban krama desa dan tamiu antara lain:

1. Kewajiban Krama Adat antara lain:

a. Mengikuti aturan sesuai dengan Awig-Awig, Perarem, dan Ketentuan Desa Adat.

b. Tidak boleh membuka usaha, sesuai dengan Awig-Awig Desa Adat Canggu.

c. Siap mengikuti Krama Desa baik dan buruk.

d. Kena iuran masing-masing ayah pengarep.

2. Kewajiban Krama Tamiu antara lain:

a. Taat kepada Desa Adat menuju adat yang baik secara sekala dan niskala.

b. Tidak boleh bertentangan dengan Desa Adat.

c. Harus melaporkan kepada Kelian Banjar apabila menerima tamiu lebih dari 24 jam.

d. Membayar iuran pada Pura Kahyangan sesuai dengan kewajiban.

3. Kewajiban Tamiu antara lain:

a. Patuh kepada aturan Desa Adat seperti masalah masyarakat dan pertanahan.

b. Tidak boleh bertentangan dengan Awig-Awig Desa Adat Canggu.

c. Harus melaporkan kepada Kelian Banjar apabila menerima tamiu lebih dari 24 jam.

d. Kena iuran sesuai dengan keperluan.

Dengan berpedoman kepada Pararem Desa Adat Canggu Badung tersebut, dapatlah dikatakan bahwa krama desa adat pengarep saja yang memiliki kedudukan terhadap tanah karang desa.

Terkait dengan krama desa yang tidak lagi beragama Hindu di Desa Adat Canggu Badung I Nyoman Sujapa Bendesa Desa Adat Canggu Badung, mengatakan: Sehubungan dengan adanya warga yang beralih agama maka masyarakat Desa Adat Canggu Badung kemudian merefisi awig-awig desa adat yang mana isinya antara lain "asing-asing sinalih tunggil Desa Adat Canggu Badung nilar kedaton kasinanggeh warge tamiu" yang berarti, setiap warga Desa Adat Canggu Badung yang beralih agama atau sejenisnya, maka warga tersebut disebut tamu. Berdasarkan hal tersebut diataslah maka semua hak-hak desa adat wajib diserahkan kembali kepada adat, termasuk tanah karang desa yang ditempati oleh warga yang tidak lagi beragama Hindu tersebut, sehingga masyarakat tersebut tidak lagi memiliki hak-hak adat Desa Adat Canggu Badung termasuk kuburan adat yang menjadi salah satu tanah milik desa adat (Wawancara pada tanggal 21 Pebruari 2020).

Dengan adanya Pararem Pangele Desa Adat Canggu Pawos 7 tersebut maka warga yang sebelumnya merupakan masyarakat Desa Adat Canggu Badung tidak lagi menjadi warga Desa Adat Canggu Badung dan dicabut hak-hak mereka atas adat. Namun dari desa adat memberikan syarat-syarat untuk itu antara lain membayar iuran wajib dalam bentuk beras sebanyak $100 \mathrm{Kg}$. Dengan alasan kemanusiaan namun desa hanya melayani masyarakat tersebut secara administratif bukan secara adat.

Terjadinya filosofi krama Desa Adat Canggu yang beralih agama menempati tanah karang desa diawali dari adanya warga Desa Adat Canggu yang mempunyai anak salah satunya hanya perempuan karena kawin dengan orang Non-Hindu, tetapi diajak tinggal di rumahnya oleh kedua orang tuanya, sehingga anak perempuan bersama dengan suami dan anaknya merawat, ngayahang banjar, tedun ke banjar, ngayah ke Pura dan lain-lain, semua kewajiban adat dilaksanakannya walaupun dia sudah tidak beragam hindu lagi karena ikut suami. Begitu seterusnya, singkat cerita ayah ibunya meninggal, dua upacarakan layaknya warga lain, sehingga lama kelamaan karena tidak ada yang menuntut, suami istri dan anak-anak itulah yang menempati tanah karang desa tersebut.

Namun karena suami istri tersebut Non-Hindu, digugatlah oleh warga lain agar diharuskan kembali masalah penempatan karang desa tersebut. Akhirnya dikembalikan sesuai dengan Awig-Awig Pasal 4 yaitu : yang disebut warga desa Adat Canggu adalah warga yang beragama Hindu, menempati tanah 
karang desa, yang telah menempati tanah karang desa tersebut serta patuh terhadap Awig-Awig dan Pararem Desa Adat.

\section{SIMPULAN DAN SARAN}

Berdasarkan uraian tersebut diatas dapatlah ditarik simpulan sebagai berikut: 1) Hak dan kewajiban krama desa yang menempati tanah karang desa sesuai dengan awig-awig Desa Adat Canggu Badung adalah untuk menempati tanah karang desa, mengingat krama desa yang menempati tanah karang desa telah diatur dalam Awig-Awig Desa Adat Canggu, Pawos 4 Ayat (1) serta berkewajiban ikut mebanjar, melaksanakan ayahan desa dan membayar iuran. 2) Kedudukan krama desa yang tidak lagi beragama Hindu terhadap tanah karang desa sesuai dengan awig-awig Desa Adat Canggu Badung setiap krama desa yang beralih agama, maka krama tersebut disebut krama tamiu. Berdasarkan hal tersebut, maka semua harta atau fasilitas desa adat wajib diserahkan kembali kepada desa adat, termasuk tanah karang desa yang ditempatinya, seperti tercantum dalam Pararem Desa Adat Canggu, Pawos 4 Ayat (3). Sesuai dengan simpulan tersebut diatas, apapun saran yang dapat diberikan yaitu 1) Kepada Bendesa Desa Adat supaya mempertegas keberadaan tanah adat dan krama Desa Adat yang menempati tanah karang desa seperti yang termuat dalam Pararem Desa Adat Canggu. 2) Kepada masyarakat adat yang menempati tanah adat dalam bentuk tanah karang desa untuk dipahami bahwa hal ini terkait dalam agama dan keyakinan masyarakat tersebut, karena di dalamnya menyangkut hak dan kewajiban desa adat dan masyarakat adat, dan 3) Kepada peneliti selanjutnya untuk mengkaji lebih dalam mengenai tanggungjawab dari krama desa yang beralih agama.

\section{DAFTAR PUSTAKA}

Ardana, I. G. G. (2007). Pemberdayaan Kearifan Lokal Masyarakat Bali dalam Menghadapi Budaya Global. Denpasar: Pustaka Tarukan Agung.

Aspriani, D. A. O., Budiono, A. R., \& Sirtha, I. N. (2013). Status Kepemilikan Tanah Druwe Desa di Bali. Jurnal Hukum, l(1). $\quad$ Retrieved from http://hukum.studentjournal.ub.ac.id/index.php/hukum/article/view/445

Bauto, L. M. (2016). Perspektif Agama dan Kebudayaan dalam Kehidupan Masyarakat Indonesia (Suatu Tinjauan Sosiologi Agama). Jurnal Pendidikan Ilmu Sosial, 23(2), 11. doi:10.17509/jpis.v23i2.1616

Dewi, N. M. L. L. K. (2016). Peran Desa Pakraman Dalam Pembentukan Perarem Terkait Penyelesaian Konflik Alih Fungsi Lahan (Studi Kasus Di Desa Pakraman Tunjuk, Kabupaten Tabanan). Jurnal Magister Hukum Udayana (Udayana Master Law Journal), 5(3), 435. doi:10.24843/JMHU.2016.v05.i03.p02

Dharmayuda, I. M. S. (1987). Status dan fungsi tanah adat Bali setelah berlakunya UUPA. Denpasar: Kayumas Agung.

Gorda, I. G. N. (1999). Manajemen dan Kepemimpinan Desa Adat di Propinsi Bali dalam Perspektif Era Globalisasi. Denpasar: Singaraja: Sekolah Tinggi Ilmu Ekonomi Satya Dharma bekerja sama dengan Widya Kriya Gematama.

Sumunar, D. R. S., Suparmini, \& Setyawati, S. (2017). Masyarakat Desa Adat Tenganan Pegringsingan. Jurnal Penelitian Humaniora, 22(2), 111-124. Retrieved from https://journal.uny.ac.id/index.php/humaniora/article/view/19929

Surpha, I. W. (2012). Seputar Desa Pakraman dan Desa Adat Bali. Denpasar: Pustaka Bali Post.

Suryawan, I. M. (2018). Status Hukum Krama Desa Adat Yang Beralih Agama Hindu Terkait Tanah Karang Desa (Studi Kasus Di Br. Gria Cucukan, Desa Selat, Klungkung). Jurnal Bakti Saraswati, 7(1). Retrieved from http://e-journal.unmas.ac.id/index.php/baktisaraswati/article/view/152

Suwitra, I. M. (2011). Eksistensi Hak Penguasaan dan Pemilikan atas Tanah Adat Di Bali Dalam Perspektif Hukum Agraria Nasional. Bandung: Logus Publishing.

Trinaya D, A. A. M. A. (2019). Kepastian Hukum Penguasaan Tanah Adat Oleh Desa Pakraman Tusan Banjarangkan. Kerta Dyatmika, 16(2). doi:https://doi.org/10.46650/kd.16.2.733.12-21

Urbanus, N., \& Febianti. (2017). Analisis Dampak Perkembangan Pariwisata Terhadap Perilaku Konsumtif 
Masyarakat Wilayah Bali Selatan. Jurnal Kepariwisataan Dan Hospitalitas, 1(2), 118-133. Retrieved from https://ojs.unud.ac.id/index.php/jkh/article/view/35148

Waluyo, B. (2002). Penelitian Hukum Dalam Praktek. Jakarta: Sinar Grafika.

Wiguna, M. O. C. (2018). Memahami Pertalian Desa Pakraman di Bali Dengan Karang Ayahan Sebagai Bagian Dari Palemahan Berdasarkan Konsep Tri Hita Karana. Jurnal Panorama Hukum, 3(2), 125140. doi:10.21067/jph.v3i2.2728

Wirawan, K. A., Sukadana, I. K., \& Suryanata, C. G. (2019). Status Tanah Karang Desa Di Desa Pakraman Selat Belega. Kertha Wicaksana, 13(1). doi:https://doi.org/10.22225/kw.13.1.995.12-18 